\title{
Structural reform of the Reserve Bank of Australia
}

\author{
Peter Tulip ${ }^{1}$
}

\section{Abstract}

The Reserve Bank of Australia (RBA) recently placed higher priority on stabilising household debt than on its conventional goals of unemployment and inflation. This was bad economics, bad process and resulted in substantial unnecessary hardship. However, it was not unusual. The RBA has a record of poor decisions. That partly reflects poor process and a lack of expertise. More fundamentally, the RBA has a culture that places a low priority on getting the answers right. To address these problems, more monetary policy experts should be appointed to the RBA Board, and board members should be individually accountable for their votes. The RBA should be required to be more transparent - in particular, it needs to provide detailed explanations for its decisions and it needs to show alternative projections for interest rates. Decisions should be explained and defended at regular press conferences.

\section{Problems}

\section{The need for a review}

A major review of monetary policy has been called for by leading economists, newspaper editorials, the Australian Labor Party and many others (Wright, 2021b; $\mathrm{SMH}, 2021$; The Age, 2021). This note discusses the main issues I think a review should cover.

1 Chief Economist, Centre for Independent Studies; ptulip@cis.org.au. I worked at the RBA from 2011 to 2020. While this paper is informed by that experience, I have kept internal discussions confidential. All factual statements are consistent with publicly available information. Thanks to William Coleman, Chris Edmond, Jerome Fahrer, Stephen Kirchner, Andrew Leigh, Paul Ryan and Dmitry Titkov for comments. All opinions are mine. 
The case for a review is simple. The RBA has been failing to meet its statutory objectives.

Underlying inflation has fallen below the target of 2-3 per cent and unemployment has substantially exceeded estimates of its sustainable rate of about 4.5 per cent. These misses persisted for more than five years.

The failures were expected, not accidental. They preceded the Covid-19 pandemic. In November 2019, the RBA forecast inflation would remain below its target range and unemployment would remain well above the non-accelerating inflation rate of unemployment (NAIRU) throughout the forecast horizon. Despite this obviously unsatisfactory outlook, the bank left interest rates unchanged at its November meeting and at subsequent meetings. This followed several years of reluctance to cut rates. As a result, when the pandemic hit, Australian unemployment was already too high, so the hardship caused by the recession was much worse than it would have been had the starting point been better.

These failures create a presumption that reform is needed. This is especially so given that the agreement with the government on the Conduct of Monetary Policy (RBA, 2016) specifies that the inflation target is 'a clearly identifiable performance benchmark'.

Bruce Preston (2020), Stephen Kirchner (2018, 2021), Ross Garnaut (2021, pp. 68-78) and Zac Gross (2019) have written strong critiques of the RBA and called for fundamental reforms. Andrew Leigh has made similar arguments in parliamentary hearings (Lowe, 2019, 2020). As Shane Wright (2021a) reports, these views are widespread among monetary policy experts. My arguments are similar, differing mainly in emphasis and detail. Nevertheless, a restatement and extension seem useful. I discuss flaws in RBA decision-making and communication, and suggest remedies.

The mistakes discussed in the first part of the paper provide sufficient grounds for the reforms discussed in the second part, but they are not necessary. Most major central banks around the world conduct regular external reviews. Many have implemented the reforms I suggest. Even if one agrees with recent RBA decisions, there is still a strong case for review and reform.

\section{The debt mistake}

I argue that the RBA regularly makes bad decisions. These are not just differences in judgement or disagreements about economics, but serious analytical errors. This paper is not the place to substantiate all of these in detail. Instead, this section explains the issue of indebtedness, as it has been the most important controversy facing the bank. 
The main reason the RBA knowingly missed its inflation and unemployment targets was the belief that cutting interest rates would increase financial instability.

The most common version of this argument centres on bank failures and the need to avoid a repetition of the Global Financial Crisis (GFC). However, a large body of research surveyed by the International Monetary Fund (IMF, 2015), Saunders and Tulip (2019) and Svensson (2017) finds that this argument is flawed.

The RBA's position is different, focusing on household debt. Before the pandemic, the bank often summarised its policy position along the following lines: 'For some time, the Board has been seeking to balance the benefits of stimulatory monetary policy with the medium-term risks associated with high and rising levels of household debt' (Lowe, 2017b).

What are these risks? The fullest explanation of which I am aware is Lowe (2017a):

[T] he issue we have focused on is the possibility of future sharp cuts in household spending because of stretched balance sheets. Given the high levels of debt and housing prices, relative to incomes, it is likely that some households respond to a future shock to income or housing prices by deciding that they have borrowed too much. This could prompt a sharp contraction in their spending, as they try to get their balance sheets back into better shape. An otherwise manageable downturn could be turned into something more serious.

There are many flaws in this argument, any one of which would be fatal.

First, monetary policy has negligible effects on the debt-income ratio. Many (possibly most) empirical estimates find that the short-run effect is in the opposite direction to that claimed by the RBA. According to the IMF (2015, p. 15), the Bank of Canada (2016, Box 7) and others, low interest rates boost the denominator (income) by more than the numerator (debt). That is, monetary policy has bigger effects on the ability to service debt than it does on the debt itself. In the longer run, macroeconomic models assume that monetary policy does not affect real variables, such as the debt-income ratio.

Second, the number of instruments should equal the number of targets. Given that indebtedness is a structural problem (the debt-income ratio has trended up since the 1950s), it should be addressed with a structural instrument, like prudential controls or tax, not a cyclical instrument like monetary policy.

Third, in models in which debt increases consumption volatility (for example, Debelle, 2004), it does so by reducing after-interest disposable income or net wealth. Lower interest rates may boost nominal debt, but they raise after-interest disposable income (as households are net borrowers at variable rates) and net wealth (as asset values increase more than debt). So, lower interest rates reduce volatility. 
Fourth, even if policy could affect indebtedness (though not net wealth or disposable income), indebtedness has very little effect on aggregate spending volatility. There is microeconomic evidence that variations in indebtedness explain variations in spending between households. However, it does not appear to be important in explaining aggregate variations over time-the dimension that monetary policy affects. Although the ratio of debt to income has more than quintupled (!) over the past few decades, the responsiveness of consumption to wealth has not significantly changed (see, for example, May et al., 2019, Graphs 4, 5, 7). Rather than showing signs of increasing 'fragility', the overall volatility of consumption has fallen substantially (until the pandemic, at least). Aggregate consumption forecasting equations do not include interactions with debt.

The most directly relevant research on this question is probably Kearns et al. (2020, Section 3.2.6). They consider a 40 per cent fall in real house prices, which might be considered a 'worst-case' or 'once-in-a-lifetime' scenario. With low debt, consumption falls 10.8 per cent. With high debt, consumption falls 11.5 per cent. That is a difference of only 0.7 per cent for an extreme shock, despite a huge 30 -percentage-point increase in the debt-income ratio-an increase that is orders of magnitude larger than anything that monetary policy might cause. And this greatly overstates the total effect because it assumes no offsetting monetary policy. In practice, lower interest rates would neutralise the shock, as in Ballantyne et al. (2019, Figure 16).

This tiny difference, which might occur once in a lifetime, cannot justify maintaining unemployment a percentage point above the NAIRU, as the RBA has done. Maintaining high interest rates to avoid an increase in indebtedness would not pass any reasonable cost-benefit comparison.

The RBA's mistake on debt will hopefully not recur. However, it raises deeper issues about how the bank is governed. First, the RBA has no process by which this mistake could be identified or corrected, which is discussed further below. Second, the argument was never explained or defended in public, which is discussed further below.

\section{Other policy mistakes}

The RBA's mistake on financial stability was not a one-off that might be rectified by reversing a decision or moving particular individuals. It was just the most important in a string of poor decisions, suggesting the problems are more fundamental. Arguing the merits of each of these mistakes is beyond the scope of this paper and is not the point. But some examples establish a prima facie case. 
A second argument for not cutting interest rates more aggressively was that the bank should 'keep its powder dry' or 'keep some ammunition in reserve'. As Bruce Preston (2017, p. 91) discusses, this argument is perverse and is inconsistent with a wide range of macroeconomic models. Ben Bernanke (2010) notes the 'strong consensus among researchers that [at low rates] policymakers should lower rates preemptively'. According to John Williams (2009, p. 6), '[k]eeping your powder dry is precisely the worst thing to do'.

A third factor behind recent failures is what Paul Keating (2020) has described as the RBA's culture of indolence or what Gordon de Brouwer and James Gilbert (2005) call the RBA's 'deep stasis'. Keating argues the bank was 'too slow lifting interest rates in the face of the commercial bank credit bubble of the late 1980s and too slow in getting rates down in the early 1990s'. The same tardiness was repeated in 2006 and 2007, when the bank allowed inflation to rise to 5 per cent, to be fortuitously saved by the GFC. And, again, in 2016-19, when interest rates were frozen at 1.5 per cent for 34 months, despite forecasts of inflation below the target range and unemployment well above the NAIRU.

Over its history, the RBA has targeted a series of variables - the gold price, the money supply, the current account deficit, a 'checklist', the debt-income ratiowhich economists would now consider to be poor choices. Typically, the RBA adhered to the old target well after economists realised it was no longer sensible. Warwick McKibbin was pushed out of the RBA for objecting to the targeting of the current account (Martin, 2006).

In 2003 and 2015, the RBA set interest rates higher than macroeconomic conditions warranted to reduce the growth in house prices. ${ }^{2}$ But recently Governor Philip Lowe (2021) said this 'would be the wrong thing to do and I don't think it would work'.

I touch on further mistakes, like the bank's aversion to negative interest rates, below. Stephen Kirchner (in this volume) criticises policy during the pandemic.

Of course, everyone makes mistakes, and best practice in monetary policy is constantly evolving. The examples above simply illustrate that the RBA is no different. The problem is the RBA has no mechanism for identifying-let alone correcting - poor decisions. As discussed below, neither the board nor parliamentary oversight committees nor the public has enough information and expertise to properly evaluate policy. If anything, the RBA has a structure-centring on one fallible individual, accountable to non-economists, with secretive decisions- that

2 As discussed, the RBA's direct communication was unclear. In particular, the bank did not give public reasons for its decisions (though it did background journalists, off the record). Ian Macfarlane, 17 years after the event, explains that 'house prices stopped rising ... certainly that's what we were trying to achieve' (Walker, 2020, at 1:14). After the April 2015 meeting, several newspapers ran stories with headlines like 'RBA puts fear of rising house prices before jobs'. 
makes mistakes more likely and more persistent. So, even if one agreed with past RBA decisions, there is no reason for confidence in the decisions made by future personnel.

It is arguable that the RBA makes too many mistakes. The structural flaws noted above would predict that. Moreover, most of the examples above involve the RBA taking positions that differ from modern mainstream macroeconomics. Without debating the economics of each example, it is noteworthy that justifications of the bank's positions are hard to find. For example, there may be economists who think household indebtedness is a good reason for keeping unemployment high and inflation low. If so, they have not elaborated on that in public.

In defence of the RBA, it is often argued that Australian macroeconomic outcomes have been good-relative to history, other countries and other benchmarks. To some extent, this reflects luck: the GFC fortuitously occurred when the economy had been allowed to seriously overheat; and the trend increase in export prices represents a succession of unexpected favourable supply shocks. But delving into historical counterfactuals is rarely convincing. The more important point is that one can always do better.

\section{Poor communication}

Unsatisfactory outcomes and decisions have been accompanied by unsatisfactory communication — a point emphasised by Preston (2020).

For example, the bank's unusual position on debt has never been fully explained or defended. There are brief, vague assertions in speeches, rarely exceeding a few sentences. There is no attempt at quantification of the relevant effects. There are few references to evidence or research in support (and the few references that are provided seem of doubtful relevance). Counterarguments are not addressed or even mentioned. Whereas foreign central banks will typically invite, or even commission, external experts to critique the official position, the RBA has avoided external engagement on this issue.

As another example, the bank has repeatedly said that negative interest rates were 'extraordinarily unlikely'. However, a large and growing body of research—surveyed by a BIS Working Group (Potter \& Smets, 2019), Miguel Boucinha and Lorenzo Burlon (2020) of the European Central Bank, Jeffrey Campbell, Thomas B. King, Anna Orlik and Rebecca Zarutskie (2020) of the US Federal Reserve, Luis BrandaoMarques and Gaston Gelos (2021) of the IMF and Silvana Tenreyro (2021) of the Bank of England-finds that negative interest rates are helpful in lowering unemployment and raising inflation. In my view, it would be open and honest for the RBA to acknowledge that its policy runs counter to the available research 
and to explain why it thinks this research is mistaken. But that is not the bank's style. (Though, to be fair, a year after announcing its position, the bank answered questions on it at parliamentary hearings.)

Regular monetary policy statements provide scant reasons for decisions. As noted in footnote 2 , the bank has targeted house prices, radically broadening its mandate, without saying so explicitly. More importantly, minutes and statements following board decisions rarely discuss the pros and cons of alternative choices. They do not explain why alternative paths for interest rates were not chosen. This failure, more than most, distinguishes RBA statements from Qvigstad's (2019) criteria for 'good' decisions. It makes it very difficult for outsiders to engage.

The bank is much more transparent now than in the past. Stevens (2007) documents large advances through 2007; progress since then has been more impressive. Recent policy statements have been explicit about the bank's objectives. The Bank now publishes much more detail about its forecasts. The governor has started giving press conferences. This is all great. But more should be done.

\section{Poor process}

The bank's poor decisions and communication are of concern on their own; however, they also reflect deeper problems.

The lack of external discussion seems to reflect a lack of internal deliberation. The published board minutes rarely convey serious discussion of these issues. It might be objected that the minutes are intended to be a brief summary, however, Lowe (2019, p. 23) describes them as 'very comprehensive'.

Governor Lowe (2020, p. 12) has noted dissension within the staff: 'Each month [I] listen to many of my staff telling me I've got it fundamentally wrong. They tell me, "You've got this all screwed up".' The RBA minutes do not record these disputes being presented to the board and certainly do not record the board adjudicating these disputes. So, presumably, Governor Lowe adjudicates them himself. The pitfalls in that process are obvious.

RBA publications do not address, or even mention, prominent counterarguments to bank policy, nor are they mentioned in freedom-of-information disclosures. There is little public evidence that counterarguments are given serious consideration.

The lack of internal and external discussion arguably reflects poor values. An organisation intent on getting the answers right will invite criticism and external scrutiny. An organisation that is more interested in public relations will avoid mentioning doubts or contrary opinions. 


\section{Remedies}

\section{Change the board's composition ${ }^{3}$}

Many of the RBA's problems-policy mistakes, lack of communication, lack of deliberation - can be attributed to a lack of expertise on the board. Most members lack formal training in macroeconomics and are unfamiliar with monetary policy. Consequently, they are unable to challenge the governor. They are capable of asking a good question, but they cannot argue for an alternative policy. The natural consequence is that mistakes are not identified, let alone corrected.

The lack of expertise makes some specific mistakes more likely. A board that lacks confidence in its grasp of the issues will tend to wait until the need for action is obvious-hence, Keating's observation of tardiness. Similarly, the board is unduly swayed by public opinion. Vocal pressure groups, like interest-dependent retirees, are given more weight than marginalised groups like the unemployed. ${ }^{4}$

One would expect a lack of expertise to make board deliberations superficial, and this can be seen in the minutes. Most board members are not able to discuss research or technical questions. Before parliamentary committees, RBA representatives have repeatedly evaded questions about whether board members understand central concepts in monetary policy (Lowe, 2019, p. 24). Whereas foreign central banks frame their discussions of monetary policy in terms of optimal control and stochastic simulations, a discussion of the Taylor Rule would be too sophisticated for our board (it doesn't show up in a Google search).

This aversion to expertise seeps down throughout the bank. At other central banks, policymakers request briefings on academic issues and will commission research that might help resolve policy uncertainties. A staff that services non-economists will not be required to think about these questions. Moreover, if technicalities and research issues cannot be raised in the bank's central policy documents, they will tend not be discussed. A comparison of publications shows the RBA is less interested than other central banks in modelling, research frontiers and alternative policies. It has a culture in which the formatting of charts is given more attention than the policy framework.

\footnotetext{
3 Kirchner (2021) makes similar arguments.

4 The November 2019 minutes gave, as a leading reason for not cutting interest rates, 'the negative effects of lower interest rates on savers and confidence'-not mentioning that positive effects on borrowers are larger (and by most economic criteria, more important) than those on savers. (And, as an aside, the claimed effect on confidence is another assertion refuted by the available research—for example, Kirchner, 2020.)
} 
The current composition of the RBA Board reflects outdated practices and rules, which were enacted in 1959 (with tweaks in 2007). In contrast, there has been a strong trend to increased expertise at foreign central banks. For example, whereas one of the 12 voting members of the Federal Open Market Committee (FOMC) had graduate training in economics (including a Master's) in 1949, that proportion had risen to eight of 12 by 2014 (Fox, 2014).

There would be a good case for reform of the RBA Board even if the bank had a strong record. Too much power is currently placed in the hands of one fallible individual; there need to be more checks on his discretion.

Kevin Warsh (2014, p. 24), in his review of the Bank of England, argues that ' $[\mathrm{t}]$ here is a large and growing literature on optimal design of monetary policy committees ... And there is an emerging consensus that well-designed committees tend to make better-quality decisions than individuals.

The state of the art in central bank design is to have a small committee of experts. Reforms at the Bank of England are a good example; at the Reserve Bank of New Zealand, a bit less so. So far, the RBA has been lucky to have talented individuals in charge, but it has weak safeguards should a zealot or incompetent be appointed. ${ }^{5}$

Calling for more expertise does not mean the board should be composed entirely of monetary policy experts. The research surveyed by Warsh and, more recently, David Archer and Andrew Levin (2018) finds that diversity in membership helps committees reach better decisions. It encourages assumptions to be challenged and conclusions to be questioned.

The most desirable dimension of diversity is of opinion. As John Stuart Mill wrote in On Liberty, 'it is only by the collision of adverse opinions that the remainder of the truth has any chance of being supplied'. So, one wants a mix of hawks and doves, of interventionists and free-marketeers, of researchers who emphasise data and those who emphasise theory. Diversity in background and demographic mix helps with this.

Instead, we currently have a diversity of competence. A few members of the board have the knowledge and technical ability to challenge the governor; most do not. That kind of diversity does little to reduce groupthink or insularity.

5 This is a real possibility. US President Donald Trump nominated Judith Shelton to the FOMC. Former RBA Governor Bernie Fraser (1991) said: 'I won't go just to appease some dickhead minister who wants to put Attila the Hun in charge of monetary policy.' 


\section{Individual accountability}

Having board members capable of challenging the governor is not enough. They also need an incentive. This means individual accountability and identified votes. Individual policymakers should publicly explain their views on policy and where they agree and disagree.

It is not in the bank's private interest to air disagreements and objections; it would be bad publicity and raise doubts. It is often described as 'a bad look-because disagreement is interpreted as a cacophony, a sign of confusion or indecisiveness or that decisions have not been thought through. But an open contest of ideas is in the public interest. This is how understanding advances. Getting the decisions right is more important than appearances. It is true that airing disagreements makes the public uncertain, but where there is disagreement, there should be uncertainty! So, public votes and explanations should be required at the board level.

'Consensus' is undoubtedly comfortable for the governor, who has his decisions rubber-stamped, but consensus necessarily stifles innovation. It promotes groupthink, insularity and status quo bias, leading sources of error.

The RBA prevents its researchers from discussing their work in academic forums if the subject is 'sensitive' (that is, relevant to policy). An indirect benefit of airing disagreements at the board level would be that staff could more freely engage with external experts, to mutual benefit.

Apart from improving decision-making, this is democratic. The public has a right to know how appointed decision-makers act and why.

Former RBA Board member Richard Warburton opposed individual accountability because it would expose external board members to 'undue criticism and pressure from the sectorial groups they nominally represent' (quoted in Kirchner, 2008). Stevens (2007) discusses similar arguments. As Kirchner points out, this argument highlights the conflict of interest that is inherent in appointing part-time business executives. And it is counterintuitive. Normally, conflicts of interest are restrained by transparency, not secrecy.

\section{Transparency}

The bank would make fewer and less persistent mistakes if it was required to explain its decisions in public. We already require that administrative and judicial decisions be explained in a way that facilitates review and appeal. We should have higher standards for monetary policy, given that it affects millions of households and that the RBA has a large staff to do the drafting. Checks on bureaucratic discretion should be tighter for central banks than for other institutions. 
Good decision-making processes recognise that mistakes sometimes happen and decision-makers do not wish to expose their errors, so formal processes of review are required.

The lack of transparency is a problem for many reasons (Stevens, 2007). First, explaining decisions is necessary for accountability and democracy. The public needs to have confidence that decisions are well-based, reflect society's values and do not unduly benefit favoured groups.

Second, clear understanding aids the goals and transmission of monetary policy. Uncertainty will be lower. Financial prices will react quicker and more accurately to genuine news and less to noise. Expectations of inflation will be more firmly anchored. This is especially important while relying on forward guidance.

Third, the alternative of backgrounding friendly journalists in return for favourable coverage is corrupt.

Fourth, the lack of external scrutiny leads to bad decisions. Mistakes are not identified and the range of issues considered is narrow. All the country's wisdom on monetary policy does not reside in Martin Place.

Of course, the staff of the RBA is well-placed to offer scrutiny and constructive criticism. But their promotion prospects depend on the goodwill of the governor, so without external pressure, there are disincentives for frank discussion (something freedom-of-information legislation exacerbates, but that is a separate topic).

For transparency measures to be meaningful, the bank's explanations need to be challenged and defended. International experience has shown press conferences following meetings to be effective in this. Sceptics should watch them on YouTubethey will be surprised. The RBA has been almost unique among major central banks in not having regular press conferences after meetings. As this paper was being drafted, Governor Lowe has held several press conferences. Hopefully, these will become regular.

In contrast, parliamentary oversight is less successful, either in Australia or in other countries. Politicians do not have the time, incentives or resources for effective scrutiny.

There is a large literature on how central banks should communicate. My favourites include Blinder et al. (2008), Yellen (2012), Svensson (2013) and Qvigstad and Schei (2018), but there are many others. There are many things the RBA could do better, with the following being at the top of my list.

First, show projections of the cash rate, as discussed by Glenn Rudebusch (2008). This is a clear and simple way of doing forward guidance; it provides a basis for discussing alternative policy and it is simple information that is useful to the public 
and, in particular, to financial markets. Confidence intervals can be constructed from past yield curve errors. The main objection is that the current board lacks the capacity to do it, but that needs to change anyway.

Second, show alternative paths for the cash rate and their implications for inflation and unemployment; Svensson (2013) and Yellen (2012) provide examples. This is perhaps the single most important reform. How can one have a meaningful discussion of policy choices without an understanding of their consequences?

Third, estimates of the NAIRU should be regularly updated and published. The statutory objective of full employment is usually and sensibly interpreted as keeping unemployment near the NAIRU.

Fourth, we need more accountability for past errors. For example, when the RBA misses its targets, as it has done for the past several years, it needs to explain why. Otherwise, it is difficult to learn and to avoid future misses. We know that some recent misses were deliberate and some were due to forecasting errors, but we do not know how much.

Among the forecasting errors we do not know how much was model error and how much was judgement. Was the bank's persistent overoptimism the result of wishful thinking or bad luck? The model error can be decomposed. For example, was too much/too little weight put on estimates of the NAIRU or the exchange rate or some other influence ${ }^{6}$ The individuals and institutions involved in creating forecasts have a clear incentive not to draw attention to mistakes. However, it is hard to see how forecasting can improve without quantitative post-mortems. Again, they should be required.

\section{The Reserve Bank's mandate}

The specification of central bank objectives is a large topic beyond the scope of this paper. Moreover, it is of secondary importance to questions of governance. There is little point in revising the RBA's objectives if the bank is going to ignore them. That said, some aspects of the mandate overlap with the rest of the discussion.

\section{Financial stability should not be an objective of monetary policy ${ }^{7}$}

Many of the current problems arose because monetary policy was misdirected from its conventional objectives towards the stabilisation of household balance sheets.

6 Cassidy et al. (2019) find that the bank's models of inflation explain historical variations well. Similar decompositions should be done for forecast errors.

7 Kirchner $(2018 ; 2021$, pp. 10-13) provides a good discussion. 
This debate has progressed since it was between 'poppers versus moppers' or 'lean versus clean'. In the wake of the GFC, no one argues that cleaning up after a financial crisis is adequate. Central banks clearly need to take preemptive action to prevent bank failures. Rather, the issue is whether interest rates are a better instrument for this than prudential controls. The overwhelming thrust of expert opinion, outside the RBA, is 'no'. See, for example, the surveys by Saunders and Tulip (2019) or the IMF (2015). The research finds that interest rates are about as likely to create instability as to reduce it; either way, the effect is minimal. High interest rates cause substantial collateral damage. In contrast, other instruments such as capital requirements are efficient, effective and low-cost.

The Agreement between the Government and the RBA needs to be reworded. A variation on the Agreement of September 2010 would clarify that financial stability is subordinate to inflation and full employment: 'Without compromising the price stability or full employment objectives, the Reserve Bank seeks to use its powers where appropriate to promote the stability of the Australian financial system' (emphasis added).

It could usefully be added that prudential controls are a more cost-effective instrument. And the changes made in the September 2016 Agreement, which explicitly mentioned financial stability as an objective, should be reversed. Kirchner (2018) discusses the evolution of the wording of this Agreement.

\section{Full employment should be an explicit objective}

The 'About Monetary Policy' webpage linked to on the RBA website's home page says:

The principal medium-term objective of monetary policy is to control inflation, so an inflation target is thus the centrepiece of the monetary policy framework. The Governor and the Treasurer have agreed that the appropriate target for monetary policy is to achieve an inflation rate of $2-3$ per cent, on average, over time.

In statements like these, full employment is secondary. For example, the agreement between the government and the RBA merely says that the RBA 'takes account' of employment.

In practice, the RBA is not an inflation nutter; it pursues a dual mandate. That is consistent with recent bank statements, modern research, the bank's legislation and the practice (though not the rhetoric) of most other central banks. The bank should be honest and explicit about this in its central documents. For example, the agreement with the government should say: 'The goals of the RBA are maximum sustainable employment and inflation of 2-3 per cent'-perhaps with further detail noting the RBA's current estimate of maximum sustainable employment, recognising that this will evolve over time. The central banks of New Zealand and the United States have recently adopted wording like this. 
This change is partly symbolic, helping to bring language into line with practice. It also has practical implications, one of which is preventing a reversion to earlier neglect.

Another practical objective relevant to recent experience is to reduce confusion about the horizon over which the bank should achieve its targets. As noted above, the agreement says 'over time'. The vagueness of this understandably annoys many observers, such as Preston (2020). However, in my view, the remedy is not to be more specific about timing; it is to be specific about the reason for lags-namely, trade-offs. Faced with a supply shock, it is sensible to approach targets gradually; trying to hit one target quickly would mean a big deviation in the other. However, faced with a demand shock, when there is no trade-off between objectives, policy should move aggressively to achieve both targets very quickly. ${ }^{8}$ This confusion is one reason for the tardiness of which Keating has complained.

Another practical implication is when a shock delivers a large temporary shock to inflation and a persistent shock to activity of the opposite sign, as the United Kingdom encountered in 2009. Then the Bank of England (correctly) reduced interest rates even though inflation was temporarily high. Public communication was impeded by the ostensible inflation target, with widespread complaints that the bank was ignoring its statutory obligations.

\section{Conclusion}

Ultimately, the RBA Board should be accountable for failures of the institution, but sacking the board and replacing them with similar people would be pointless. Another group of part-time business leaders would be expected to make similar mistakes. We need to change the kind of people on the board and their incentives.

The RBA possesses many of the most talented, dedicated economists in the country. However, the incentives and constraints they operate under make mistakes likely and persistent. In particular, we need to subject decisions to expert scrutiny, both inside and outside the bank.

\section{References}

Archer, D. \& Levin, A.T. (2018). Robust design principles for monetary policy committees (Conference volume). Reserve Bank of Australia. Available from: www.rba.gov.au/ publications/confs/2018/pdf/rba-conference-volume-2018-archer-levin.pdf.

8 To be precise, the appropriate policy is to minimise a loss function with unemployment and inflation as arguments. In my view, quadratic loss and equal weights are consistent with the relative social costs of unemployment and inflation, but that is a matter of judgement. 
Ballantyne, A., Cusbert, T., Evans, R., Guttmann, R., Hambur, J., Hamilton, A., Kendall, E., McCririck, R., Nodari, G. \& Rees, D. (2019). MARTIN has its place: A macroeconometric model of the Australian economy (RBA Research Discussion Paper, RDP 2019-07). Reserve Bank of Australia. Available from: www.rba.gov.au/publications/rdp/ 2019/2019-07/full.html.

Bank of Canada. (2016). Renewal of the inflation-control target (Background Information, October 2016). Bank of Canada. Available from: www.bankofcanada.ca/wp-content/ uploads/2016/10/background_nov11.pdf.

Bernanke, B. (2010). Monetary policy and the housing bubble. Speech to Annual Meeting of the American Economic Association, Atlanta, GA, 3 January. Available from: www.federal reserve.gov/newsevents/speech/bernanke20100103a.htm.

Blinder, A.S., Ehrmann, M., Fratzscher, M., De Haan, J. \& Jansen, D.-J. (2008). Central bank communication and monetary policy: A survey of theory and evidence. Journal of Economic Literature, 46(4), 910-45. Available from: www.aeaweb.org/articles?id=10.1257/ jel.46.4.910. doi.org/10.3386/w13932.

Boucinha, M. \& Burlon, L. (2020). Negative rates and the transmission of monetary policy (ECB Economic Bulletin, Issue 3/2020). European Central Bank. Available from: www.ecb.europa.eu/pub/economic-bulletin/articles/2020/html/ecb.ebart202003_ 02 4768be84e7.en.html.

Brandao-Marques, L. \& Gelos, G. (2021). The evidence is in on negative interest rate policies. IMFBlog, 3 March. International Monetary Fund. Available from: blogs.imf.org/2021/03/ 03/the-evidence-is-in-on-negative-interest-rate-policies/.

Campbell, J., King, T.B., Orlik, A. \& Zarutskie, R. (2020). Issues regarding the use of the policy rate tool (Finance and Economics Discussion Series 2020-070). Board of Governors of the Federal Reserve System. doi.org/10.17016/FEDS.2020.070.

Cassidy, N., Rankin, E., Read, M. \& Seibold, C. (2019). Explaining low inflation using models (RBA Bulletin, 20 June). Reserve Bank of Australia. Available from: www.rba.gov. au/publications/bulletin/2019/jun/explaining-low-inflation-using-models.html.

Debelle, G. (2004). Macroeconomic implications of rising household debt (BIS Working Papers No. 153). Bank for International Settlements. Available from: www.bis.org/publ/ work153.htm. doi.org/10.2139/ssrn.786385.

de Brouwer, G. \& Gilbert, J. (2005). Monetary policy reaction functions in Australia. Economic Record, 81(253), 124-34. doi.org/10.1111/j.1475-4932.2005.00238.x.

Fox, J. (2014). How economics PhDs took over the Federal Reserve. Harvard Business Review, 3 February. Available from: hbr.org/2014/02/how-economics-phds-took-overthe-federal-reserve.

Fraser, B. (1991). Reserve chief attacks GST. Sydney Morning Herald, 23 November, 1.

Garnaut, R. (2021). Reset. La Trobe University Press. 
Gross, Z. (2019). Various posts about the RBA, Medium. Available from: medium.com/@ ZacGross.

International Monetary Fund (IMF). (2015). Monetary policy and financial stability (Staff Report, 28 August). International Monetary Fund. Available from: www.imf.org/external/ np/pp/eng/2015/082815a.pdf.

Kearns, J., Major, M. \& Norman, D. (2020). How risky is Australian household debt? (RBA Research Discussion Paper, RDP 2020-05). Reserve Bank of Australia. Available from: www.rba.gov.au/publications/rdp/2020/2020-05.html.

Keating, P. (2020). The 'Reverse Bank' has to quickly rediscover the gear stick. Sydney Morning Herald, 23 September. Available from: www.smh.com.au/national/keating-thereverse-bank-has-to-quickly-rediscover-the-gear-stick-20200923-p55yh5.html.

Kirchner, S. (2008). A 'new era' for the Reserve Bank? Policy, 24(1), 18-24. Available from: www.institutional-economics.com/images/uploads/ANewErafortheRBA.pdf.

Kirchner, S. (2018). Money too tight to mention: The Reserve Bank of Australia's financial stability mandate and low inflation. Economic Analysis and Policy, 60, 141-49. Available from: www.sciencedirect.com/science/article/abs/pii/S0313592618302455. doi.org/10.1016/j.eap.2018.09.014.

Kirchner, S. (2020). The effect of changes in monetary policy on consumer and business confidence. Australian Economic Review, 53(1), 118-25. doi.org/10.1111/1467-8462. 12365 .

Kirchner, S. (2021). Reforming Australian monetary policy: How nominal income targeting can help get the Reserve Bank back on track (Monetary Policy Working Papers, 27 January). Mercatus Center, George Mason University. doi.org/10.2139/ssrn.3777444.

Lowe, P. (2017a). Household debt, housing prices and resilience. Speech, Economic Society of Australia (Qld) Business Lunch, Brisbane, 4 May. Available from: www.rba.gov.au/ speeches/2017/sp-gov-2017-05-04.html.

Lowe, P. (2017b). Remarks at Reserve Bank Board dinner, Brisbane, 5 September. Available from: www.rba.gov.au/speeches/2017/sp-gov-2017-09-05.html.

Lowe, P. (2019). Reserve Bank of Australia annual report 2018 (Official Committee Hansard, 9 August). House of Representatives Standing Committee on Economics. Available from: parlinfo.aph.gov.au/parlInfo/search/display/display.w3p;query=Id\%3A\%22committees \%2Fcommrep\%2Fcd2f4ebe-8e89-48fc-9d73-511ad37ff580\%2F0001\%22.

Lowe, P. (2020). Reserve Bank of Australia annual report 2019 (Official Committee Hansard, 2 December). House of Representatives Standing Committee on Economics. Available from: parlinfo.aph.gov.au/parlInfo/download/committees/commrep/4c225357-9226-403 c-b656-6ee06c9f2b2f/toc_pdf/Standing\%20Committee\%20on\%20Economics_2020 _12_02_8387_Official.pdf;fileType=application $\% 2 \mathrm{Fpdf} \#$ search $=\% 22 \mathrm{committees} /$ commrep/4c225357-9226-403c-b656-6ee06c9f2b2f/0000\%22. 
Lowe, P. (2021). The labour market and monetary policy. Speech, Economic Society of Australia (Qld), Online, 8 July. Available from: webcast.boardroom.media/player/ reserve-bank-of-australia/20210706/NaN60e287a8f25582001a23efcc.

Martin, P. (2006). Saturday Forum: The impressive Warwick McKibbin. Available from: www.petermartin.com.au/2006/12/impressive-warwick-mckibbin.html.

May, D., Nodari, G. \& Rees, D. (2019). Wealth and consumption (RBA Bulletin, 21 March). Reserve Bank of Australia. Available from: www.rba.gov.au/publications/bulletin/2019/ mar/wealth-and-consumption.html.

Potter, S.M. \& Smets, F. (2019). Unconventional monetary policy tools: A cross-country analysis (CGFS Papers No. 63). Committee on the Global Financial System, Bank for International Settlements. Available from: www.bis.org/publ/cgfs63.pdf.

Preston, B. (2017). Is monetary policy less effective when interest rates are persistently low? Discussant: Bruce Preston. In J. Hambur \& J. Simon (eds), Monetary Policy and Financial Stability in a World of Low Interest Rates: Proceedings of a Conference Held in Sydney on 16-17 March 2017. Reserve Bank of Australia. Available from: www.rba.gov. au/publications/confs/2017/pdf/rba-conference-volume-2017.pdf.

Preston, B. (2020). The case for reform of the RBA's policy and communication strategy (CAMA Working Paper 3/2020, January). Centre for Applied Macroeconomic Analysis, The Australian National University. Available from: cama.crawford.anu.edu.au/sites/ default/files/publication/cama_crawford_anu_edu_au/2020-01/3_2020_preston.pdf.

Qvigstad, J.F. (2019). How to draft 'good' minutes of monetary policy decisions. Economic Affairs, 39(1), 44-64. doi.org/10.1111/ecaf.12329.

Qvigstad, J.F. \& Schei, T. (2018). Criteria for 'good' justifications (Norges Bank Working Paper No. 6/2018). Norges Bank. Available from: www.norges-bank.no/en/news-events/ news-publications/Papers/Working-Papers/2018/62018/.

Reserve Bank of Australia (RBA). (2016). Statement on the Conduct of Monetary Policy. Reserve Bank of Australia. Available from www.rba.gov.au/monetary-policy/framework/ stmt-conduct-mp-7-2016-09-19.html.

Rudebusch, G.D. (2008). Publishing central bank interest rate forecasts (FRBSF Economic Letter 2008-02, 25 January). Federal Reserve Bank of San Francisco. Available from: www.frbsf.org/economic-research/publications/economic-letter/2008/january/ publishing-central-bank-interest-rate-forecasts/.

Saunders, T. \& Tulip, P. (2019). Cost-benefit analysis of leaning against the wind (RBA Research Discussion Paper, RDP 2019-05). Reserve Bank of Australia. doi.org/10.2139/ ssrn.3435992.

Stevens, G. (2007). Central bank communication. Address to The Sydney Institute, Sydney, 11 December. Available from: rba.gov.au/speeches/2007/sp-gov-111207.html. 
Svensson, L.E.O. (2013). Some lessons from six years of practical inflation targeting. Sveriges Riksbank Economic Review, 2013(3)[SI], 28-80. Available from: larseosvensson.se/files/ papers/Svensson-paper--Some-lessons-from-six-years-of-practical-inflation-targeting.pdf.

Svensson, L.E.O. (2017). Cost-benefit analysis of leaning against the wind. Journal of Monetary Economics, 90(October), 193-213. doi.org/10.1016/j.jmoneco.2017.07.004.

Sydney Morning Herald (SMH). (2021). RBA review could look at ways to avert the next crisis. Sydney Morning Herald, [Editorial], 7 April. Available from: www.smh.com.au/ business/the-economy/rba-review-could-look-at-ways-to-avert-the-next-crisis-20210407p57h6b.html.

Tenreyro, S. (2021). Let's talk about negative rates. Speech, UWE Bristol webinar, 11 January. Bank of England. Available form: www.bankofengland.co.uk/-/media/boe/ files/speech/2021/january/lets-talk-about-negative-interest-rates-speech-by-silvanatenreyro.pdf?la=en\&hash=254710E731E1D2347AE5BEE0907934C1EDC6742.

The Age. (2021). RBA review could look at ways to avert the next crisis. [Editorial], The Age, [Melbourne], 7 April. Available from: www.theage.com.au/business/the-economy/rbareview-could-look-at-ways-to-avert-the-next-crisis-20210407-p57h6l.html.

Walker, J. (2020). \#83: The silent hero of the Australian economy-Ian Macfarlane. The Jolly Swagman Podcast, 15 January. Available from: josephnoelwalker.com/77-ian-macfarlane/.

Warsh, K. (2014). Transparency and the Bank of England's Monetary Policy Committee (Review, December). Bank of England. Available from: www.hoover.org/sites/default/ files/transparency_and_the_bank_of_englands_monetary_policy_committee.pdf.

Williams, J. (2009). Heeding Daedalus: Optimal inflation and the zero lower bound (Brookings Papers on Economic Activity No. 2). Brookings Institution Press. doi.org/ 10.1353/eca.0.0066.

Wright, S. (2021a). The central bank under fire: Has the RBA failed Australians? Sydney Morning Herald, 6 April. Available from: www.smh.com.au/politics/federal/the-centralbank-under-fire-has-the-rba-failed-australians-20210315-p57auu.html.

Wright, S. (2021b). 'Crucial but not beyond reproach': Labor joins calls for review of RBA. Sydney Morning Herald, 7 April. Available from: www.smh.com.au/politics/federal/crucialbut-not-beyond-reproach-labor-joins-calls-for-review-of-rba-20210316-p57b2i.html.

Yellen, J.L. (2012). Revolution and evolution in central bank communications. Speech, Haas School of Business, University of California, Berkeley, 13 November. Board of Governors of the Federal Reserve System. Available from: www.federalreserve.gov/ newsevents/speech/yellen20121113a.htm. 
This text is taken from Agenda, Volume 28 - Number 1, 2021 edited by William Coleman, published 2021 by ANU Press, The Australian National University, Canberra, Australia.

doi.org/10.22459/AG.28.01.2021.09 